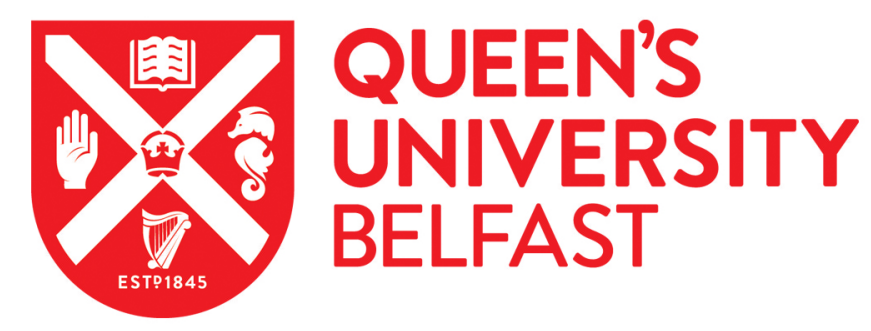

\title{
Cleft Lip Case in a Middle Bronze Age Young Man from Altai, Russia
}

Tur, S. S., Svyatko, S. V., \& Nechvaloda, A. I. (2017). Cleft Lip Case in a Middle Bronze Age Young Man from Altai, Russia. International Journal of Osteoarchaeology, 27(2), 276-287. https://doi.org/10.1002/oa.2538

Published in:

International Journal of Osteoarchaeology

Document Version:

Peer reviewed version

Queen's University Belfast - Research Portal:

Link to publication record in Queen's University Belfast Research Portal

Publisher rights

Copyright $\odot 2016$ John Wiley \& Sons, Ltd. This work is made available online in accordance with the publisher's policies. Please refer to any applicable terms of use of the publisher.

\section{General rights}

Copyright for the publications made accessible via the Queen's University Belfast Research Portal is retained by the author(s) and / or other copyright owners and it is a condition of accessing these publications that users recognise and abide by the legal requirements associated with these rights.

Take down policy

The Research Portal is Queen's institutional repository that provides access to Queen's research output. Every effort has been made to ensure that content in the Research Portal does not infringe any person's rights, or applicable UK laws. If you discover content in the Research Portal that you believe breaches copyright or violates any law, please contact openaccess@qub.ac.uk. 


\section{Cleft Lip Case in a Middle Bronze Age Young Man from Altai, Russia}

\begin{tabular}{|r|l|}
\hline Journal: & International Journal of Osteoarchaeology \\
\hline Manuscript ID & OA-15-0149.R1 \\
\hline Wiley - Manuscript type: & Research Article \\
\hline Complete List of Authors: & $\begin{array}{l}\text { Tur, Svetlana; Altai State University, Museum of Archaeology and } \\
\text { Ethnography of Altai } \\
\text { Svyatko, Svetlana; Queen's University of Belfast, 14CHRONO Centre for } \\
\text { Climate, the Environment, and Chronology } \\
\text { Nechvaloda, Aleksei; Institute of History, Language and Literature, Ufa } \\
\text { Scientific Centre of the Russion Academy of the Sciences, Department of } \\
\text { Ethnology }\end{array}$ \\
\hline Keywords: & $\begin{array}{l}\text { congenital anomalies, cleft lip and palate, paleopathology, Altai, Middle } \\
\text { Bronze Age, } \delta<\text { sup }>13</ \text { sup }>C \text { and } \delta<\text { sup }>15</ \text { sup }>\text { N isotope analysis }\end{array}$ \\
\hline &
\end{tabular}


Cleft Lip Case in a Middle Bronze Age Young Man from Altai, Russia

Running title: Cleft Lip in a Middle Bronze Age Man

\author{
S. S. TUR, ${ }^{a}$ S. V. SVYATKO ${ }^{b} *$ AND A. I. NECHVALODA ${ }^{c}$ \\ ${ }^{\mathrm{a}}$ Museum of Archaeology and Ethnography of Altai, Altai State University, Barnaul, Russia \\ ${ }^{\mathrm{b}}{ }^{14}$ CHRONO Centre for Climate, the Environment, and Chronology; Queen's University of \\ Belfast, Northern Ireland, UK \\ ${ }^{c}$ Institute of History, Language and Literature, Ufa Scientific Centre of the Russian Academy of \\ Sciences, Ufa, Russia
}

*Correspondence to: Dr. Svetlana Svyatko, 14CHRONO Centre for Climate, the Environment, and Chronology; Queen's University of Belfast, Belfast BT7 1NN, Northern Ireland, UK.

E-mail: s.svyatko@qub.ac.uk

\begin{abstract}
Oral cleft (OC) is a common congenital anomaly in humans, which occurs in approximately one per 700 live births. However, cleft skulls are found relatively seldom in archaeological specimens, especially for the BC period. Mortality of infants with OC was apparently high due to breastfeeding difficulties and culturally sanctioned rejection of them in the past. This paper presents one of the most ancient cases of oral cleft in Eurasia. The finding comes from the Middle Bronze Age pastoralists' cemetery in Altai, Russia. The skeletal remains have been radiocarbon dated to $1883-1665$ cal $\mathrm{BC}$. Cranial and dental measurements, computed tomography and radiography have been used to examine this malformation. The facial sculpting reconstruction has been performed to visualize the ante mortem appearance of the cleft face. Besides, $\delta^{13} \mathrm{C}$ and $\delta^{15} \mathrm{~N}$ isotope analysis was used for a comparative study of the diet of the cleft individual. It has been established that a young man from Altai was affected by complete bilateral cleft lip and alveolus which is a very rare form of typical OC. This defect is associated with dental anomalies such as hypodontia, microdontia, and ectopia as well as with dysmorphology of the facial complex outside the cleft area, including mild hypertelorism, hypoplasia of nasal bones and antheroposterior maxillary deficiency. Furthermore, aplasia of the frontal sinuses and the sacral spina bifida occulta have been observed. These findings are consistent with clinical data indicating strong correlation between development of a major defect and multiple minor anomalies. The results of the study also suggest that there was tolerant attitude towards the facial deformities among the ancient Altai pastoralists.
\end{abstract}

Key words: congenital anomalies; cleft lip and palate; paleopathology; Altai; Middle Bronze Age; $\delta^{13} \mathrm{C}$ and $\delta^{15} \mathrm{~N}$ isotope analysis

\title{
Introduction
}

Oral cleft (OC) is a common congenital anomaly in humans, which occurs in approximately one per 700 live births, with wide racial, ethnic and geographic variations (e.g. Vanderas, 1987; Tolarova \& Cervenka 1998). The phenotypic spectrum of OCs comprises of multiple patterns varying in affected structure (the lip, alveolus, hard or soft palate including the uvula), laterality (median, left, right, bilateral) and severity (incomplete, complete). The incisive foramen is a key point for classification of these defects (Figure 1S). Traditionally, they have subdivided into two main categories - cleft of the lip/alveolus with or without cleft of the palate (CL $\pm \mathrm{P})$ and cleft of the palate only (CP), based on their differences in embryologic development and epidemiology 
(Fogh-Andersen 1942; Fraser, 1955). However, recent studies suggest that cleft lip/alveolus only (CL) and cleft lip/alveolus with cleft palate (CLP) also have etiological and pathogenetic differences (Harville et al., 2005; Jugessur et al., 2009; Carrol and Mossey, 2012).

The causes of OC are complex and involve both genetic and environmental factors. The birth defect can appear as an isolated, non-syndromic anomaly or as a part of recognized genetic syndromes - monogenic, chromosomal, environmentally-induced, or of unknown genesis (Cohen, 1978; Tolarová \& Cervenka, 1998). In syndromic OCs, which account for nearly 30\% of all cases, associated malformations most frequently affect the skeletal, central nervous and cardiovascular systems (Shprintzen et al., 1985; Milerad et al., 1997; Stoll et al., 2000; Sekhon et al., 2011). Relative to the background population, infants with OC, especially syndromic, have significantly higher mortality during their first year of life (Hujoel et al., 1992; Ngai et al., 2005). Cleft individuals often experience problems with feeding, hearing, speaking, and social integration (Clarren et al., 1987; Drake \& Roush 2013; .Riski, 2013).

The congenital defects were probably not less common in the past than they are today. However, cleft skulls are found relatively seldom in archaeological specimens. The finds date to the Neolithic through the $18^{\text {th }} \mathrm{c}$. AD, with their majority attributing to period after the middle of the $1^{\text {st }}$ mil. AD. Isolated cleft palate has been diagnosed most frequently (Brooks \& Hohenthal, 1963; Giardino, 1980; Brothwell, 1981; Fiori, 1983; Gladykowska-Rzeczycka 1989; Hegyi et al.; 2004; Phillips \& Sivilich, 2006; Weiss, 2008; Hawass et al., 2010; Liston \& Rotroff, 2013), followed by unilateral cleft lip and palate (Gilkey, 1978; Anderson, 1994; Altamirano Enciso \& Garsía-Zarata, 2010). Besides, individual cases of unilateral cleft lip and alveolus, premaxillary agenesis, and cleft lip only have been documented (Munizaga, 1961; Berndorfer, 1962; Hegyi et al., 2002; 2004; Lewis, 2013; Pachajoa \& Rodriguez, 2013). It should be noted that not all of those cases may be confidently considered as congenital malformations due to associated postmortem destruction and/or bone remodeling and porosity, suggesting trauma or infection (e.g. Alexandersen 1967; Anderson 1994; Brothwell, 2010).

In archaeological contexts, OCs have been recorded for both children and adults, however, there is no evidence for cleft infants under about three year of age from formal cemeteries which may be related to not only taphonomic but also to cultural factors. In many ancient societies youngest children were buried away from the rest of the population (Ucko, 1969). In this regard, an extraordinary deposit in a well in the Athenian Agora site $\left(2^{\text {nd }} \mathrm{c} . \mathrm{BC}\right)$, Greece, is particularly indicative. Among the excellently preserved skeletal remains of more than 400 neonates, most of whom had likely died of natural causes, incidence of OC was unusually high (Liston \& Rotroff, 2013).

As mentioned by the $16^{\text {th }}$ c. Italian anatomist Fabricius ab Aquapendente (1619), infants with cleft palate often died of malnutrition because they were unable to suck. Ethnographical sources indicate that the affected neonates had further reduced chances for survival due to infanticide, exposure or neglect (Gregg et al., 1981; Mull \& Mull, 1987; Sargent, 1987; Scheper-Hughes, 1990). The study of visible birth defects may therefore not only contribute to the picture of their prevalence in past populations, but also offers potential insights into well-being, care, and tolerance in these societies.

This paper presents one of the most ancient cases of oral cleft in Eurasia.

\section{Materials and methods}

The analyzed skeleton originates from grave 113 of the cemetery of Firsovo 14 located in the Altai region, Russia (Figure 1). Within the cemetery, more than 150 graves belonged to the Middle Bronze Age pastoralists of the Andronovo culture (unpublished reports of the Altai State University archaeological expedition, 1991-2011). Grave 113 was not anyhow different from other burials in terms of planigraphy, construction, size, grave goods, and position of the 
deceased (Figure 2S). The skeletal remains have been radiocarbon dated to 1883-1665 cal BC in the 14CHRONO Centre for Climate, the Environment, and Chronology, Queen's University of Belfast (UK) using accelerator mass spectrometry.

The skeleton has been fairly well preserved, although not all elements were available for the examination (Figure 2). Sex and age at death of the individual were determined according to standard osteological methods (Buikstra \& Ubelaker, 1994). The stature was estimated from the femur length using regression equation of Trotter and Gleser (1958). The body mass was calculated from the femoral head breadth using 'mechanical' method (Auerbach \& Ruff, 2004).

In addition to the gross visual examination of the congenital anomaly, computed tomography (CT) and computed radiography (CR) have been applied.

To determine the probable effect of clefting on the craniofacial morphology, linear variables and proportions of the cleft skull have been measured and compared to those of unaffected skulls; as a control group, a sample of sex- and age-matched skulls from the Andronovo graves of Firsovo 14 have been used. Deviation of the values of the cleft individual being more than 2SD from the group means was considered as significant.

For the reconstruction of living facial features of the cleft skull, the technique by Gerasimov $(1955,1968)$ was employed. Thickness of soft tissue was determined using dataset by RöhrerErtl and Helmer (1984).

To assess possible differences between the diet of the cleft individual and that of other members of the Andronovo society, stable $\delta^{13} \mathrm{C}$ and $\delta^{15} \mathrm{~N}$ isotope analysis was performed in the 14CHRONO Centre. The analysis allows estimating the proportions of plant versus animal components, as well the amount of the so-called $\mathrm{C}_{4}$ plants (such as maize or millet) versus $\mathrm{C}_{3}$ plants in the diet. The values of the cleft individual were compared to those of individuals from the Andronovo cemeteries of Rublevo $(n=4)$ and Chekanovskiy Log $(n=4)$ located within the Altai region.

\section{Results}

The anthropological examination suggests that the skeletal remains belonged to a 18-23 years old male, with the above the average stature of $176 \mathrm{~cm}$ and the average body mass of $70 \mathrm{~kg}$, as compared to unaffected individuals from the Firsovo 14 population.

\section{Paleopathological analysis}

Within the cranium, the main anomaly is the cleft of the medial part of the upper jaw (the premaxilla), extending as far posterior as the incisive foramen (Figure 3). Normally, the fusion of premaxilla (os incisivum or primarily palate) with the alveolar and palatal processes of the maxilla (incisive suture), the nasal cartilaginous septum and the vomer (vomero-premaxillary suture) commences in utero; the palatal component of the incisive suture closes almost completely shortly after the birth, and the vomero-premaxillary suture obliterates at about 15 years of age (Barteczko \& Jacob, 2004). In the analysed case, the premaxilla is rudimentary and articulates only with the anterior-caudal margin of the vomer. The vomero-premaxillary suture is clearly visible throughout its length. The suture between the two halves of the premaxilla (sutura intraincisiva) is preserved as well. The secondary palate, consisting anteriorly of the palatal processes of the maxilla and posteriorly of the palatal processes of the palatine, is unaffected. However, the contact between the nasal crest of the secondary palate and the vomer is absent [Figure 4(a, b, c)]. In summary, this anatomical condition represents complete bilateral cleft of the primarily palate, which is a skeletal manifestation of cleft lip and alveolus (Barnes, 2012). Sculpting reconstruction from the skull shows the living facial features of the affected man (Figure 5). 
The cleft is associated with dental anomalies, including hypodontia of the maxillary incisors and mandibular left second premolar, ectopia of the maxillary left second premolar [Figure 6(a)] and microdontia of the maxillary premolars (Table 1). The primary left second molars in both jaws have retained due to the developmental anomalies of the associated second permanent premolars, though the maxillary primary tooth has been lost post mortem [Figure 6(a, b, c)].

The major deviations of the craniofacial morphology outside the cleft area are increased width of nasal bones, distance between the inner orbital walls, and width of nasal cavity; maxillary retrognathia; reduced maxillary, mandibular, and palatal lengths, as well as palatal breadth at the canine level. The remaining craniofacial linear and proportional measurements are not extreme, and fall within the $\pm 2 \mathrm{SD}$ range of the control group (Table 2). It should be highlighted, however, that the cleft individual also has short nasal bones. A higher coefficient of variation of the nasals' length (19.4) in the reference group suggests that the latter may be heterogeneous in regard to this variable.

Computer tomography and radiography of the cleft skull have revealed bilateral absence (aplasia) of the frontal sinuses (Figure 3S). Besides, there is another congenital anomaly in the infracranial skeleton - the sacral spina bifida occulta. The posterior vertebral neural arch halves of S1, S2, and possibly S3 failed to fuse (Figure 4S). Thus, the OC of the individual is associated with multiple anomalies, both dental and minor physical.

\section{Stable isotope analysis}

Results of stable isotope analysis (mean values of the control group are $-19.0 \pm 0.4 \%$ for $\delta^{13} \mathrm{C}$ and $11.6 \pm 1.8 \%$ for $\delta^{15} \mathrm{~N}$ ) suggest that the diet of the Altai pastoralists of the Andronovo culture was based on $\mathrm{C}_{3}$-plants and included large amounts of animal protein. In relation to the proportions of plant and animal components, the diet of the cleft individual $\left(-19.4\right.$ for $\delta^{13} \mathrm{C}$ and 11.3 for $\left.\delta^{15} \mathrm{~N}\right)$ does not appear to have been different from that of other members of the community (Figure 7).

\section{Discussion}

Oral clefts are well recognizable disruptions of normal facial structure. In archaeological contexts, however, they sometimes may be confused with destruction or deformation of the maxilla as a result of specific infections, ante mortem trauma, intranasal cocaine abuse, malignancies and some other diseases (e.g. Alexandersen, 1967; Anderson, 1994; Brothwell, 2010; Gupta et al., 2012). In the present case, the acquired conditions have been immediately ruled out because there are no any traces of pathological periosteal reaction or reparation in the cleft area.

The skull from Firsovo 14 represents complete bilateral cleft of the primarily palate, being a skeletal manifestation of cleft lip and alveolus. Syndromic forms of CL are less usual than those of CLP and CP, and account for 9-17\% of all CL (Stoll et al., 2000; Harville et al., 2005; Sekhon et al., 2011). The proportion of bilateral cases among cleft lip with or without cleft alveolus is 910\% (Campbell Wilson, 1972; Shapira et al., 1999b). Prevalence of bilateral cleft lip and alveolus constitutes only $2-7 \%$ of all OCs in recent populations (Ortiz-Monasterio et al., 1974; Mars et al., 1990; Shapira et al., 1999b; Latief et al., 2010). The finding from Firsovo 14, as far as it can be inferred from available literature sources, is the first archaeologically-recovered case of this rare subtype of OC.

Individuals with $C L \pm P$ often show developmental dental anomalies not only in the region of the cleft itself but also beyond. Results of genome-wide studies suggest that some loci may contribute to both non-syndromic clefts and congenital dental anomalies (Vieira et al., 2008). Cleft lip with or without palate is commonly associated with numerical dental anomalies, such as 
hypodontia (congenital absence of one to six teeth, except third molars) and supernumerary teeth. The most frequently congenitally missing teeth are the maxillary lateral incisors, followed by the second premolars (e.g. Böhn, 1963; Lopes et al., 1991, Menezes \& Vieira, 2008). Supernumerary teeth occur primarily in the cleft area. With increasing cleft complexity, the incidence of supernumerary teeth usually decreases, whereas the incidence of hypodontia increases (Ranta, 1986; Lopes et al., 1991; Shapira et al., 1999a). Besides, CL \pm P frequently appears in combination with anomalies of tooth size and position. Microdontia may affect one or several isolated teeth, predominantly maxillary lateral incisors, or may be generalized (Foster \& Lavelle, 1971; Ranta, 1986; Werner \& Harris, 1989; Walker et al., 2009). Ectopia, or the eruption of a tooth in an abnormal position, most commonly occurs in the maxillary first molars and canines (e.g. Ranalli et al., 1986; Bjerklin et al., 1993; Silva Filho et al., 1996).

Both hypodontia of the maxillary central incisors and eruption deviation of the second maxillary premolar in the individual from Firsovo 14 are very rare patterns of developmental dental anomalies.

Numerous studies of fetal specimens, preoperative children, and unoperated adults have established that $\mathrm{OC}$ is generally combined with morphological changes in other regions of the craniofacial skeleton (e.g. Yoshida et al., 1992; Silva Filho et al. 1998; Kreiborg \& Hermann, 2002). Obviously, the greater interorbital and nasal cavity widths are the two most pronounced and consistent features associated with $\mathrm{CL} \pm \mathrm{P}$ (Ward et al., 2002). Both are present in the Firsovo 14 skull as well (Table 1). Distance between the inner orbital walls exceeding 2SD of the reference mean is defined as hypertelorism (Tessier, 1976; Cohen et al., 1995). This condition is both etiologically and pathogenetically heterogenous and can be found in many craniofacial syndromes and anomalies (Cohen et al., 1995). However, patients with nonsyndromic CL $\pm \mathrm{P}$ usually show mild hypertelorism (Moss, 1965; Aduss et al., 1971; Farkas et al., 1972; Figalova et al., 1974) which does not have functional and cosmetical significance.

In the analyzed skull, antheroposterior maxillary deficiency and increased contribution of the mandibular component to the face height are further in agreement with altered patterns of craniofacial shape in untreated cleft individuals (Levin 1963; Silva Filho et al. 1998). Besides, short length of nasal bones is probably associated with the OC as well. Nasal bones length is commonly short in Down syndrome cases (Keeling et al., 1997), but recently it has been indicated that fetuses with isolated CL also may have shorter-than-normal nasal bone lengths (Hansen et al., 2005; Nielsen et al., 2005).

Prevalence of the sacral spina bifida occulta and aplasia of the frontal sinuses in the OC clinical samples has not been reported in medical literature. In the general populations, the former occurs in 17-30\% (Boone et al., 1985; Fidas et al., 1987), the latter - in 1-25\% (Pondé et al., 2008; Çakur, 2011). Aplasia of the frontal sinuses is an intrinsic feature of some syndromes with midface hypoplasia (for instance, it occurs in 90\% of Down syndrome cases; CastriotaScanderbeg and Dallapiccola, 2005). Both anomalies are usually asymptomatic.

In clinical practice, congenital malformations have traditionally been divided into the 'major' and 'minor'. The isolated minor physical anomalies (MPA) are of little medical or cosmetical concern. External or visible MPA may involve any part of the body. However, they are primarily localized on the head (head circumference outside the normal range, fine electric hair, mild hypertelorism, low seated, malformed, or asymmetrical ears), hands (curved fifth finger, single transverse palmar crease), and feet (third toe longer than second, partial syndactylia of two middle toes, big gap between first and second toes). One or two MPA can develop in a healthy individual, three or more MPA occur commonly in individuals with a major anomaly or disordered behavior (Marden et al., 1964; Firestone, 1983; Leppig et al., 1987). The archaeologically-recovered CL provides additional evidence for strong correlation between appearance of a major defect and multiple minor anomalies. 
While OC is not a directly life-threatening condition, chances for infants with this defect to survive into adulthood were apparently low in the past. Many studies have shown that infants with OC have an increased risk of developing breastfeeding difficulties which may lead to malnutrition and dehydration (e.g. Avedian \& Ruberg, 1980; Jones, 1988). In breastfeeding, generation of negative intra-oral pressure is the main factor of sucking. Babies with extensive CP or CLP fail to produce negative pressure because their oral cavity cannot be adequately separated from the nasal cavity during feeding (Clarren et al., 1987; Mizuno et al., 2002; Reid et al., 2007). However, CL usually does not interfere with baby's ability to suck (Clarren et al., 1987; Reid et al., 2007). If necessary, the mother may occlude the CL with her thumb or finger and/or support the infant's cheeks to decrease the width of the cleft and increase closure around the nipple (Reilly et al., 2013). Presence of the intact secondary palate suggests that the individual from Firsovo 14 had no severe breastfeeding difficulties.

Historical and ethnographical data have further demonstrated that culturally sanctioned rejection of a deformed child was common in the past (e.g. Williamson, 1978). At birth, the infant was carefully examined. The head and the face were of particular concern because of their visibility and great social significance. If anything was wrong, the newborn was killed, exposed, or neglected and undernourished in his family (Mull \& Mull, 1987; Sargent, 1987; ScheperHughes, 1990).

In the late medieval European, Chinese, Korean, and Indonesian artwork, individuals with a cleft lip anomaly are usually portrayed in a negative light, reflecting the fact that this defect was a source of lifelong social stigma and discrimination (Saman et al., 2012). Unfavorable reaction to facial deformities have been strongly influenced by popular understanding of the cause of such conditions as a crime (satanic or bestial intercourse) or misfortune. Generally widespread was a belief that a pregnant woman can produce a deformity in her child by sighting deformed individual (Shaw, 1981). In 1708, Frederick V of Denmark even ruled that no individual with a facial deformity might show himself to a pregnant woman (Weiser-Aall, 1963).

However, in some ancient societies, there was a positive attitude to facial deformities. Ceramic art of pre-Columbian South and Central Americas represents many examples of facial clefts in very realistic portrayals of noble persons - presumably political, social, or religious leaders (Saman et al., 2012). The god of fertility and renewal was also often depicted with bilateral cleft lip (ibid.). Some Southern American Native Indian populations believed that those suffering from congenital anomalies were anointed by gods (Valera, 1879; Carod-Artal \& Vázquez Cabrera, 2006).

Inconsistent attitude towards facial clefts has been documented for Northeast Brazilian shantytowns where deformed older children and adults were extremely rarely encountered. Babies who could not suck vigorously at the nipple were immediately labeled as unfit for life. However, those cleft children who did manage to survive in such precarious environment were treated with more than tolerance. Sometimes they even were lionized by parents and other relatives, and pointed out as exemplary individuals (Scheper-Hughes, 1990).

The attempt to identify attitudes to cleft individuals in archaeological populations is rather challenging. Nevertheless, taking into account that the young man from Firsovo 14 was well developed physically (had the stature above the average and average body mass), shared the same diet, and was buried in the same manner and with the same kind of grave goods as most males of his community, it can be assumed that individuals with cleft face were not stigmatized and discriminated in the Andronovo community.

\section{Conclusions}

The presented case of oral cleft is one of the most ancient in Eurasia. The bilateral cleft lip and alveolus in a young man from the Middle Bronze Age Altai is a relatively rare subtype of 
OC, with the occurrence rate of $2-7 \%$ in recent populations, and which is recorded in archaeological materials for the first time. This malformation is associated with a number of dental anomalies and dysmorphology of the facial complex, including mild hypertelorism, nasal bones hypoplasia, and antheroposterior maxillary deficiency, as well as aplasia of the frontal sinuses and the sacral spina bifida occulta.

Analysis of the biological profile, diet, and burial context of the cleft individual suggests that there was tolerance towards the facial deformities among the ancient Altai pastoralists.

\section{Acknowledgements}

This work has been supported by the Ministry of Education and Science of the Russian Federation grant 14.Z50.31.0010 (project 'The Earliest Colonization of Siberia: Formation and Dynamics of the North Asian Cultures').We would like to express our thankfulness to Dr. G.G. Kravchenko (Tomsk State University) for providing us with the map, Dr. S.A. Pechenin (Federal Centre of Traumatology, Orthopaedy and Endoprosthesis, Barnaul) for CT images, and to Dr. A.B. Shamshin (Altai State University) for the burial plan. We are also thankful to the anonymous reviewers for their useful comments.

\section{Supporting information}

Figure 1S. Diagrams schowing various types of oral clefts.

Figure 2S. Plan of grave 113 in the Firsovo 14 cemetery.

Figure 3S. Anteroposterior radiography of the cleft skull showing aplasia of the frontal sinuses.

Figure 4S. The sacral bone of the cleft individual showing spina bifida occulta.

\section{References}

Aduss H, Pruzansky S, Miller M. 1971. Interorbital distance in cleft lip and palate. Teratology 4: $171-181$.

Alexandersen V. 1967. The pathology of the jaws and temporomandibular joint. In Diseases in antiquity, Brothwell D, Sandison AT (ed.). CC Tomas: Springfield; 551-595.

Altamirano Enciso AJ, García-Zapata MTA. 2010. Un caso de fisura labiopalatina o "boca-de-lobo" en Makatampu, valle del Rimac, Perú, siglos XV-XVI. Revista do Museu de Arqueologia e Etnologia, São Paulo 20: 361-380.

Anderson T. 1994. Medieval example of cleft lip and palate from St.Gregory's Priory, Canterbury. Cleft Palate-Craniofacial Journal 31:466-472.

Auerbach BM, Ruff CB. 2004. Human body mass estimation: a comparison of 'morphometric' and 'mechanical' methods. American Journal of Physical Anthropology 125: 331-342. DOI: 10.1002/ajpa.20032.

Avedian LV, Ruberg RL. 1980. Impaired weight gain in cleft palate infants. Cleft Palate Journal 17: 24-26.

Barnes E. 2012. Atlas of developmental field anomalies of the human skeleton: a paleopathology perspective. Wiley-Blackwell.

Barteczko K, Jacob M. 2004. A re-evaluation of the premaxillary bone in humans. Anatomy and Embryology 207: 417-437.

Berndorfer A. 1962. A 500-year-old skull with cleft lip. British Journal of Plastic Surgery 15: $123-$ 128. 
Bjerklin K, Kurol J, Paulin G. 1993. Ectopic eruption of the maxillary first permanent molars in children with cleft lip and/or palate. European Journal of Orthodontics 15: 535-540.

Böhn A. 1963. Dental anomalies in harelip and cleft palate. Acta Odontologica Scandinavica 21(suppl. 38): 1-109.

Boone D, Parsons D, Lachmann SM, Sherwood T. 1985. Spina bifida occulta: lesion or anomaly? Clinical Radiology 36:159-161.

Brooks ST, Hohenthal WD. 1963 Archaeological defective palate crania from California. American Journal of Physical Anthropology 21: 25-32.

Brothwell DR. 1981. Digging up bones. Cornell University Press: New York.

Brothwell D. 2010. On problems of differential diagnosis in palaeopathology, as illustrated by a case from prehistoric Indiana. International Journal of Osteoarchaeology 20: 621-622.

Buikstra JE, Ubelaker DH. 1994. Standards for data collection from human skeletal remains. Research. Series 44. Fayetteville: Arkansas Archeological Survey.

Çakur B, Sumbullu MA, Durna NB. 2011. Aplasia and agenesis of the frontal sinus in Turkish individuals: a retrospective study using dental volumetric tomography. International Journal of Medical Sciences 8: 278-282. DOI:10.7150/ijms.8.278.

Campbell Wilson ME. 1972. A ten-year survey of cleft lip and cleft palate in the South West Region. British Journal of Plastic Surgery 25: 224-228.

Carod-Artal FJ, Vázquez Cabrera CB. 2006. Malformaciones y parálisis faciales en la cerámica de las culturas precolombinas Moche y Lambayeque. Neurología 21: 297-303.

Carroll K, Mossey PA. 2012. Anatomical variations in clefts of the lip with or without cleft palate. Plastic Surgery International. DOI:10.1155/2012/542078.

Castriota-Scanderbeg A, Dallapiccola B. 2005. Abnormal skeletal phenotypes: from simple signs to complex diagnoses. Springer: Berlin.

Clarren SK, Anderson B, Wolf LS. 1987. Feeding infants with cleft lip, cleft palate, or cleft lip and palate. Cleft Palate Journal 24: 244-249.

Cohen MM. 1978. Syndromes with cleft lip and cleft palate. Cleft Palate Journal 15: 306-328.

Cohen MM Jr, Richieri-Costa A, Guion-Almeida ML, Saavedra D. 1995. Hypertelorism: interorbital growth, measurements, and pathogenetic considerations. International Journal of Oral and Maxillofacial Surgery 24: 387-395.

Drake AF, Roush J. 2013. Management of otopathology and hearing loss in children with cleft palate and craniofacial anomalies. In Cleft Lip and Palate: Diagnosis and Management, Berkowiiz (ed.). Springer: Heidelberg; 299-308.

Fabricius ab Aquapendente H. 1619. De Chirurgicis Operationibus. In Operationes chirurgicae in duas partes divisae. Apud Paulum Megliettum: Venezia; 34-39.

Farkas LG, Lindsay WK, Vanderby MB. 1972. Morphology of the orbital region in adults following the cleft lip/palate repair in childhood. American Journal of Physical Anthropology 37: 65-73.

Fidas A, MacDonald HL, Elton RA, Wild SR, Chisholm GD, Scott R. 1987. Prevalence and patterns of spina bifida occulta in 2707 normal adults. Clinical Radiology 38: 537-542.

Figalova P, Hajnis K, Smahel Z. 1974. The interocular distance in children with cleft before the operation. Acta Chirurgiae Plasticae 16: 65-77.

Fiori MG. 1983. Facial clefting in antiquity. Paleopathology Newsletter 44: 5.

Firestone P. 1983. Minor physical anomalies and behavior in children: a review. Journal of Autism and Developmental Disorders 13: 411-425.

Fogh-Andersen P. 1942. Inheritance of harelip and cleft palate. Munksgaard: Copenhagen. 
Foster TD, Lavelle CLB. 1971. The size of the dentition in complete cleft lip and palate. Cleft Palate Journal 8: 177-184.

Fraser FC. 1955. Thoughts on the etiology of clefts of the palate and lip. Acta Genetica et Statistica Medica 5: 358-369.

Gerasimov MM. 1955. The reconstruction of the face from the basic structure of the skull. Translated by Tschernezky. Nauka: Moscow.

Gerasimov MM. 1968. Ich suchte Gesichter. Bertelsmann: Gütersloh.

Giardino M.J.1980. Skeletal remains. The Hanna site: an Alto focus village in Red River Parish, Louisiana. Bulletin of the Louisiana Archaeological Society 5: 287-300.

Gilkey F. 1978. Cleft lip and palate in paleopathological material. Paleopathology Newsletter 24: $8-11$.

Gladykowska-Rzeczycka J. 1989. Congenital anomalies of early Polish man. In Advances in paleopathology, Capasso L (ed.). Marino Solfanelli: Chieti; 111-116.

Gregg JB, Zimmerman L, Clifford S, Gregg PS. 1981. Craniofacial anomalies in the Upper Missouri river over a millenium: archaeological and clinical evidence. Cleft Palate Journal 18: 210-222.

Gupta R, Chotaliya K, Marfatia YS. 2012. Cleft lip as a presentation of congenital syphilis. Indian Journal of Sexually Transmitted Diseases and AIDS 33: 58-59. DOI: 10.4103/0253-7184.93831.

Hansen L, Skovgaard LT, Nolting D, Hansen BF, Kjaer I. 2005. Human prenatal nasal bone lengths: normal standards and length values in fetuses with cleft lip and cleft palate. Cleft PalateCraniofacial Journal 42: 165-170. DOI: http://dx.doi.org/10.1597/03-094.1.

Harville EW, Wilcox AJ, Lie RT, Vindenes H, Abyholm F. 2005. Cleft lip and palate versus cleft lip only: are they distinct defects? American Journal of Epidemiology 162: 448-453. DOI: 10.1093/aje/kwi214.

Hawass Z., Gad YZ, Ismail S, Khairat R, Fathalla D, Hasan N, Ahmed A, Elleithy H, Ball M, Gaballah F, Wasef S, Fateen M, Amer H, Gostner P, Selim A, Zink A, Pusch CM. 2010. Ancestry and pathology in king Tutankhamun's family. Journal of the American Medical Association 303: 638-647. DOI:10.1001/jama.2010.121.

Hegyi A, Marcsik A, Kocsis GS. 2002. Developmental disorders of nasal bones in human osteoarcheological samples. Journal of Paleopathology 14: 113-119.

Hegyi A, Marcsik A, Kocsis SG. 2004. Frequency of developmental defects on the skull and the axial skeleton on skeletal collections (Hungary). Journal of Paleopathology 16: 15-25.

Hujoel PP, Bollen AM, Mueller BA. 1992. First-year mortality among infants with facial clefts. Cleft Palate-Craniofacial Journal 29(5): 451-455.

Jones WB. 1988. Weight gain and feeding in the neonate with cleft: a three-center study. Cleft Palate Journal 25: 379-384.

Jugessur A, Farlie PG, Kilpatrick N. 2009. The genetics of isolated orofacial clefts: from genotypes to subphenotypes. Oral Diseases 15: 437-453. DOI: 10.1111/j.1601-0825.2009.01577.x.

Keeling JW, Hansen BF, Kjaer I. 1997. Pattern of malformations in the axial skeleton in human trisomy 21 fetuses. American Journal of Medical Genetics 68: 466-471. DOI: 10.1002/(SICI)1096-8628(19970211)68:4<466::AID-AJMG19>3.0.CO;2-Q.

Kreiborg S, Hermann NV. 2002. Craniofacial morphology and growth in infants and young children with cleft lip and palate. In Cleft lip and palate: from origin to treatment, Wyszynski DF (ed.). Oxford University Press: Oxford; 87-97. 
Latief BS, Lekkas C, Kuijpers MAR. 2010. Maxillary arch width in unoperated adult bilateral cleft lip and alveolus and complete bilateral cleft lip and palate. Orthodontics \& Craniofacial Research 13: 82-88. DOI: 10.1111/j.1601-6343.2009.01479.x.

Leppig KA, Werler MM, Cann CI, Cook CA, Holmes LB. 1987. Predictive value of minor anomalies: I. Association with major malformations. Journal of Pediatrics 110: 531-537.

Levin HS. 1963. A cephalometric analysis of cleft palate deficiencies in the middle third of the face. Angle Orthodontist 33: 186-194.

Lewis ME. 2013. Children of the Golden Minster: St. Oswald's priory and the impact of industrialisation on child health. Hindawi Publishing Corporation Journal of Anthropology \{HYPERLINK “http://dx.doi.org/10.1155/2013/959472”.

Liston MA, Rotroff SI. 2013. Babies in the Well: Archaeological evidence for newborn disposal in Hellenistic Greece. In Oxford Handbook of Childhood and Education in the Classical World, Parkin T, Evans-Grubbs J. (ed.). Oxford University Press: Oxford; 62-81.

Lopes LD, Mattos BSC, André M. 1991. Anomalies in number of teeth in patients with lip and/or palate clefts. Brazilian Dental Journal 2: 9-17.

Marden PM, Smith DW, McDonald MJ. 1964. Congenital anomalies in the newborn infant, including minor variations. Journal of Pediatrics 64: 357-371.

Mars M, James DR, Lamabadusuriya SP. 1990. The Sri-Lankan Cleft Lip and Palate Project: the unoperated cleft lip and palate. Cleft Palate Journal 27: 3-6.

Martin R, Saller K. 1957. Lehrbuch der Anthropologie. V. I. G. Fisher Verlag: Stuttgart.

Menezes R., Vieira AR. 2008. Dental anomalies as part of the cleft spectrum. Cleft PalateCraniofacial Journal 45: 414-419. DOI: http://dx.doi.org/10.1597/07-064.1.

Milerad J, Larson O, Hagberg C, Ideberg M. 1997. Associated malformations in infants with cleft lip and palate: a prospective, population-based study. Pediatrics 100: 180-186.

Mizuno K, Ueda A, Kani K, Kawamura H. 2002. Feeding behaviour of infants with cleft lip and palate. Acta Paediatrica 91: 1227-1232. DOI: 10.1111/j.1651-2227.2002.tb00133.x.

Moss ML. 1965. Hypertelorism and cleft palate deformity. Acta Anatomica 61: 547-557. DOI:10.1159/000142714.

Mull DS, Mull JD. 1987. Infanticide among the Tarahumata of the Mexican Sierra Madre. In Child survival: anthropological perspectives on the treatment and maltreatment of children, ScheperHughes N (ed.). D. Reidel Publishing Company: Dordrecht; 113-134.

Munizaga JR. 1961. Labio leporino en una población precolombina de Chile. Antropologia Fisica Chilena 2: 49-51.

Ngai CW, Martin WL, Tonks A, Wyldes MP, Kilby M. 2005. Are isolated facial cleft lip and palate associated with increased perinatal mortality? Journal of Maternal-Fetal \& Neonatal Medicine 17(3): 203-206. DOI: 10.1080/14767050500072854.

Nielsen BW, Mølsted K, Skovgaard LT, Kjaer I. 2005. Cross-sectional study of the length of the nasal bone in cleft lip and palate subjects. Cleft Palate-Craniofacial Journal 42: 417-422. DOI: http://dx.doi.org/10.1597/04-001.1.

Ortiz-Monasterio F, Olmedo A, Trigos I, Yudovich M, Velazquez M, Fuente-del-Campo A. 1974. Final results from the delayed treatment of patients with clefts of the lip and palate. Scandinavian Journal of Plastic and Reconstructive Surgery 8: 109-115.

Pachajoa H, Rodriguez CA. 2013. Holoprosencephaly with premaxillary agenesis in a prehistoric skull. Archives of Disease in Childhood. Fetal and Neonatal Edition 98: 264. 
Phillips SM, Sivilich M. 2006. Cleft palate: a case study of disability and survival in prehistoric North America. International Journal of Osteoarchaeology 16: 528-535. DOI: 10.1002/oa.847.

Pondé, JM, Andrade RN, Via JM, Metzger P, Teles AC. 2008. Anatomical variations of the frontal sinus. International Journal of Morphology 26: 803-808. http://dx.doi.org/10.4067/S071795022008000400003.

Ranalli DN, Elliott MA, Zullo TG. 1986. Comparative analysis of ectopic eruption of maxillary permanent first molars in children with clefts. Journal of Dentistry for Children 53: 433-435.

Ranta R. 1986. A review of tooth formation in children with cleft lip/palate. American Journal of Orthodontics and Dentofacial Orthopedics 90: 11-18. DOI:10.1016/0889-5406(86)90022-3.

Reid J, Reilly S, Kilpatrick N. 2007. Sucking performance of babies with cleft conditions. Cleft Palate-Craniofacial Journal 44: 312-320. DOI: http://dx.doi.org/10.1597/05-173.

Reilly S, Reid J, Skeat J, Cahir P, Mei C, Bunik M. 2013. ABM clinical protocol \#18: guidelines for breastfeeding infants with cleft lip, cleft palate, or cleft lip and palate, revised 2013.

Breastfeeding Medicine 8: 349-353. DOI: 10.1089/bfm.2013.9988.

Riski JE. Speech, language, and velopharyngeal dysfunction: management throughout the life of an individual with cleft palate. In Cleft lip and palate: diagnosis and management. Berkowiiz (ed.). Springer: Heidelberg; 803-820.

Röhrer-Ertl O, Helmer R. 1984. Zu Stand und Möglichkeiten der erneut modifizierten KollmannMethode (Gesichtsrekonstruktion aufgrund des Schadels). Gegenbaurs Morph Jb 130:369-398.

Saman M, Gross J, Ovchinsky A, Wood-Smith D. 2012. Cleft lip and palate in the arts: a critical reflection. Cleft Palate-Craniofacial Journal 49: 129-136. DOI: http://dx.doi.org/10.1597/10079.

Sargent CF. 1987. Born to die: the fate of extraordinary children in Bariba culture. Ethnology 23: 79-96.

Scheper-Hughes N. 1990. Difference and danger: the cultural dynamics of childhood stigma, rejection, and rescue. Cleft Palate Journal 27: 301-310.

Sekhon PS, Ethunandan M, Markus AF, Krishnan G, Rao CB. 2011. Congenital anomalies associated with cleft lip and palate - an analysis of 1623 consecutive patients. Cleft PalateCraniofacial Journal 48: 371-378. DOI: http://dx.doi.org/10.1597/09-264.

Shapira Y, Lubit E, Kuftinec MM. 1999a. Congenitally missing second premolars in cleft lip and cleft palate children. American Journal of Orthodontics and Dentofacial Orthopedics 115: 396400. DOI:10.1016/S0889-5406(99)70258-1.

Shapira Y, Lubit E, Kuftinec MM, Borel G. 1999b. The distribution of clefts of the primary and secondary palates by sex, type, and location. Angle Orthodontist 69: 523-528.

Shaw WC. 1981. Folklore surrounding facial deformity and the origins of facial prejudice. British Journal of Plastic Surgery 34: 237-246.

Shprintzen RJ, Siegel-Sadewitz VL, Amato J, Goldberg RB. 1985. Anomalies associated with cleft lip, cleft palate, or both. American Journal of Medical Genetics 20: 585-595. DOI: 10.1002/ajmg.1320200404.

Silva Filho OG, Albuquerque MVP, Kurol J. 1996. Ectopic eruption of maxillary first permanent molars in children with cleft lip. Angle Orthodontist 66: 373-380.

Silva Filho OG, Carvalho Lauris RC, Capelozza Filho L, Semb G. 1998. Craniofacial morphology in adult patients with unoperated complete bilateral cleft lip and palate. Cleft Palate-Craniofacial Journal 35: 111-119. DOI: http://dx.doi.org/10.1597/15451569(1998)035<0111:CMIAPW>2.3.CO;2. 
Stoll C, Alembik Y, Dott B, Roth MP. 2000. Associated malformations in cases with oral clefts. Cleft Palate-Craniofacial Journal 37: 41-47. DOI: http://dx.doi.org/10.1597/15451569(2000)037<0041:AMICWO>2.3.CO;2.

Tessier P. 1976. Anatomical classification facial, cranio-facial and lateral-facial clefts. Journal of Maxillofacial Surgery 4: 69-92.

Tolarová MM, Cervenka J. 1998. Classification and birth prevalence of orofacial clefts. American Journal of Medical Genetics 75: 126-137.

Trotter M, Gleser G. 1958. A re-evaluation of estimation of stature based on measurements of stature taken during life and of long bones after death. American Journal of Physical Anthropology 16: 79-123.

Ucko PJ. 1969. Ethnography and archaeology interpretation of funerary remains. World Archaeology 1(2): 262-280.

Valera B, 1879. Relación de las costumbres antiguas de los naturales del Pirú. In Tres relaciones de antigüedades peruanas, Jiménez de la Espada M (ed.). Ministerio de Fomento: Madrid; 170 172.

Vanderas AP. 1987. Incidence of cleft lip, cleft palate, and cleft lip and palate among races: a review. Cleft Palate Journal 24: 216-225.

Vieira AR, McHenry TG, Daack-Hirsch S, Murray JC, Marazita ML. 2008. Candidate gene/loci studies in cleft lip/palate and dental anomalies finds novel susceptibility genes for clefts. Genetics in Medicine 10: 668-674. DOI: 10.1097GIM.0b013e3181833793.

Walker SC, Mattick CR, Hobson RS, Steen IN. 2009. Abnormal tooth size and morphology in subjects with cleft lip and/or palate in the north of England. European Journal of Orthodontics 31: 68-75. DOI: 10.1093/ejo/cjn073.

Ward RE, Moore ES, Hartsfield JK. 2002. Morphometric characteristics of subjects with oral facial clefts and their relatives. In Cleft lip and palate: from origin to treatment, Wyszynski DF (ed.). Oxford University Press: Oxford; 66-86.

Weiser-Aall L. 1963. Om haren i norsk overlevering: kilder og problemer. Univ-Forlaget: Norveg Oslo.

Weiss E. 2008. When it rains it pours: multiple congenital pathologies in single individuals. In Archaeology research trends, Suárez AR, Vásquez MN (ed.). Nova Science Publishers: New York; 65-77.

Werner SP, Harris EF. 1989. Odontometrics of the permanent teeth in cleft lip and palate: systemic size reduction and amplified asymmetry. Cleft Palate Journal 26: 36-41.

Williamson L. 1978. Infanticide: an anthropological analysis. In Infanticide and the value of life, Kohl M (ed.). Prometheus Books: New York; 61-75.

Yoshida H, Nakamura A, Michi K, Wang GM, Liu K, Qiu WL. 1992. Cephalometric analysis of maxillofacial morphology in unoperated cleft palate patients. Cleft Palate-Craniofacial Journal 29: 419-424. 


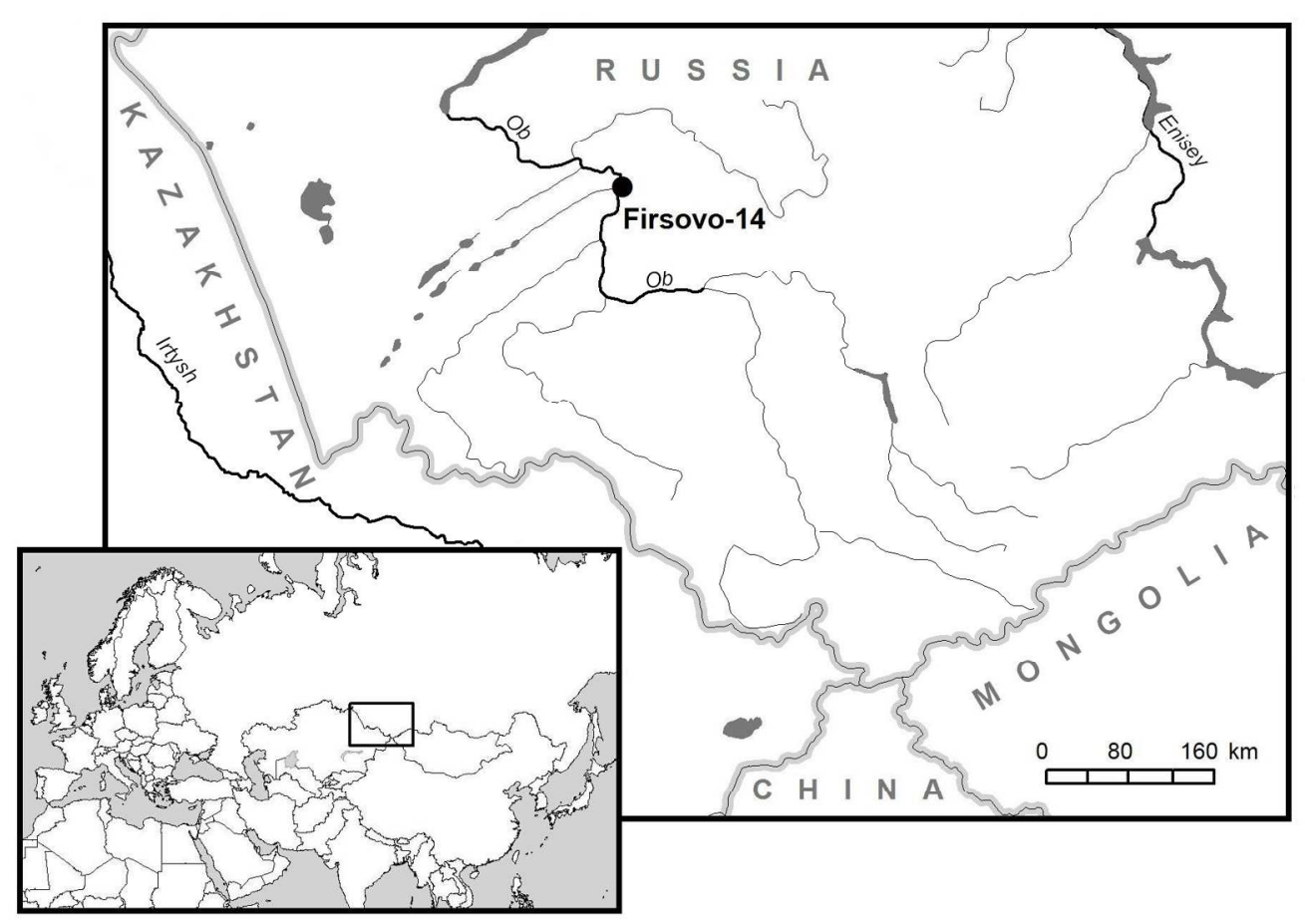

Figure 1. Location map of the Firsovo 14 cemetery. $643 \times 451 \mathrm{~mm}(72 \times 72 \mathrm{DPI})$ 


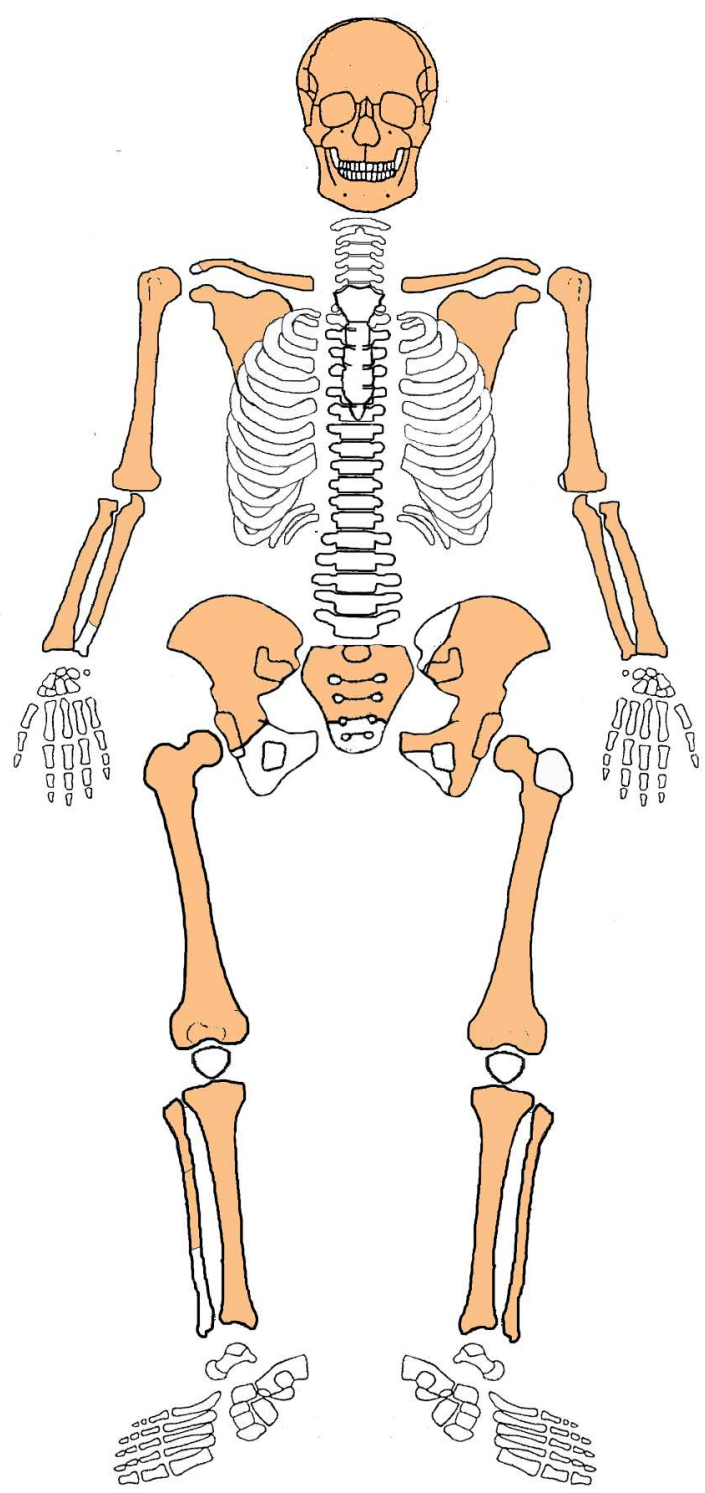

Figure 2. Available skeletal elements from grave 113 of the Firsovo 14 cemetery. This figure is available in color at wileyonlinelibrary.com/journal/oa. $123 \times 258 \mathrm{~mm}(300 \times 300 \mathrm{DPI})$ 

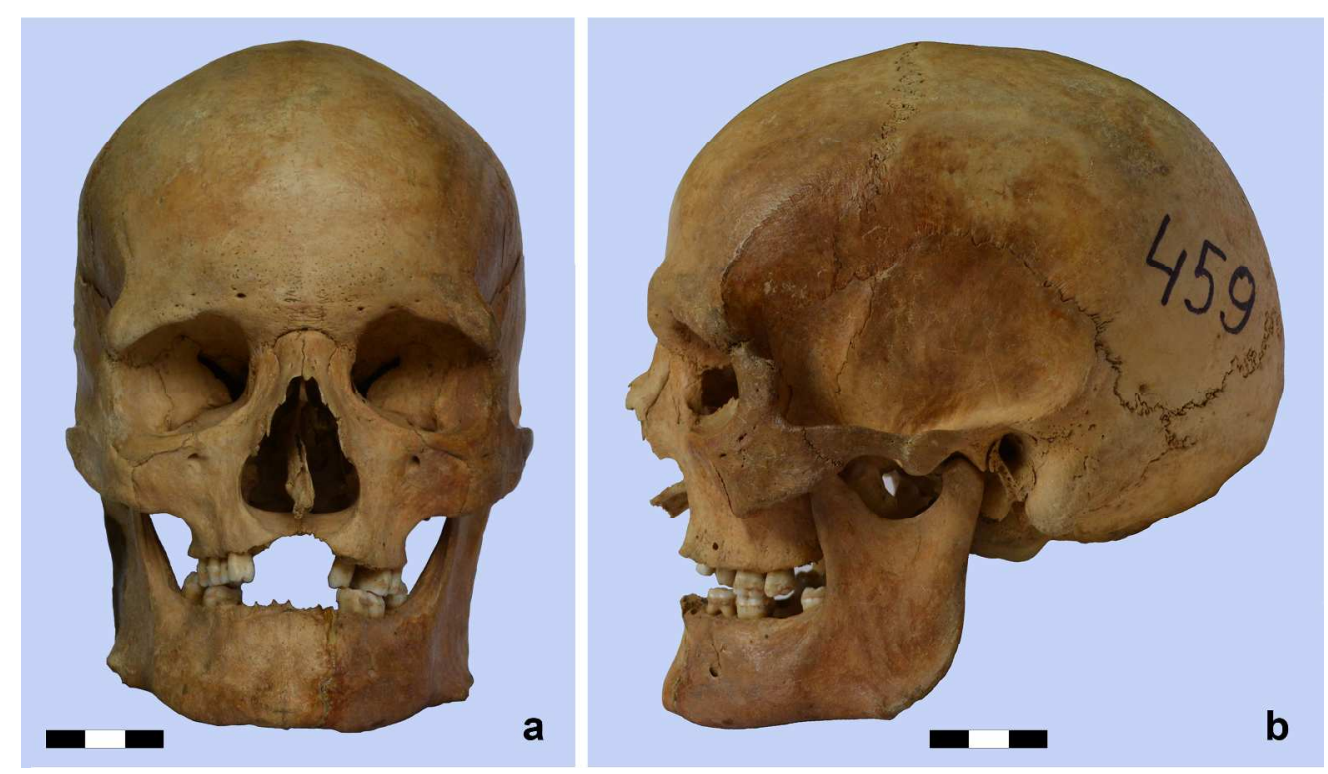

Figure 3. Anterior (a) and lateral (b) view of the cleft skull. This figure is available in color at wileyonlinelibrary.com/journal/oa. $268 \times 154 \mathrm{~mm}(300 \times 300$ DPI) 

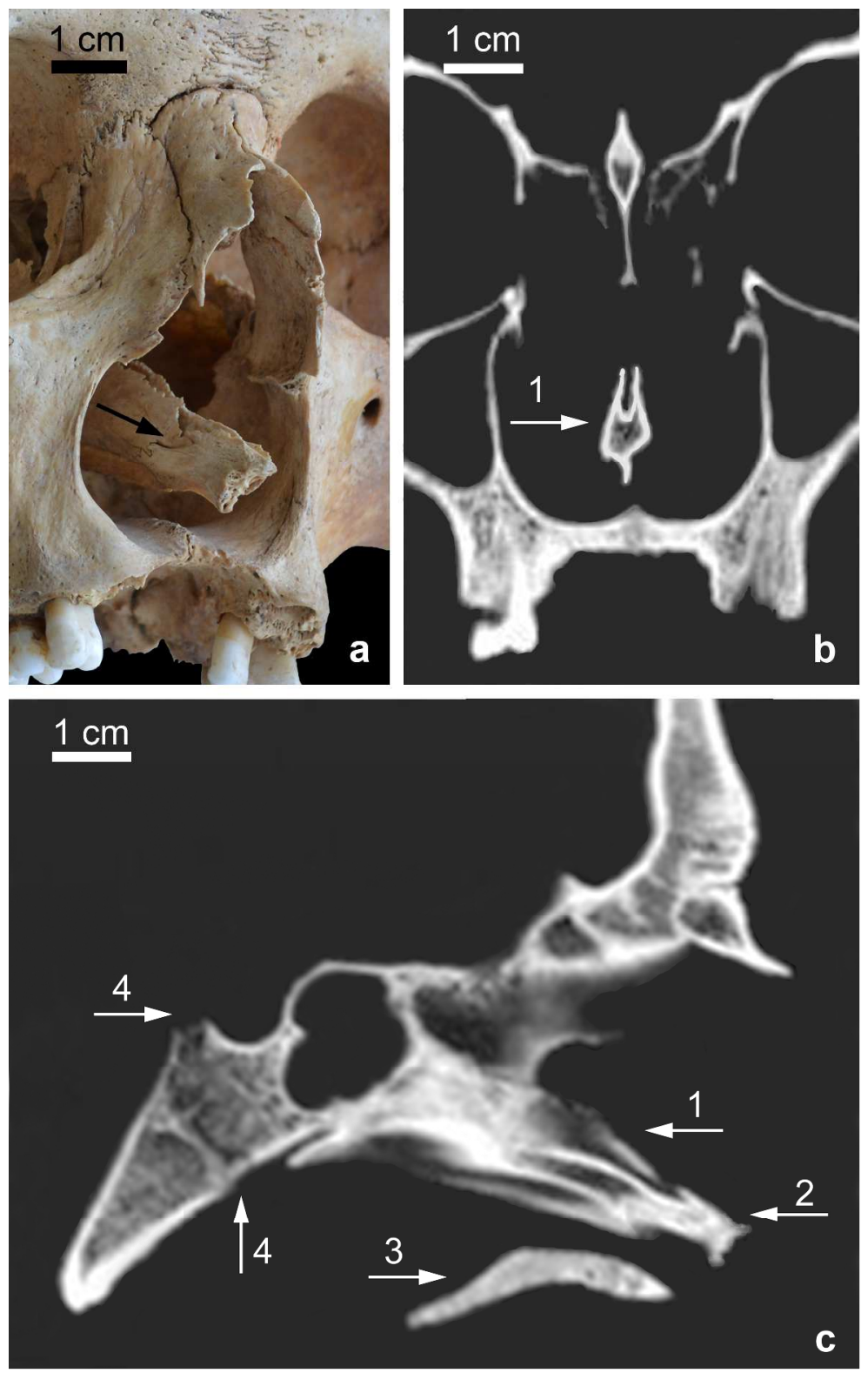

Figure 4. Photograph (a) and computed tomography coronal (b) and sagittal (c) images of the cleft skull. Arrows show the vomero-premaxillary suture (black), vomer (1), rudimentary premaxilla (2), the secondary palate (3), post mortem fracture of the skull base (4). It can be seen that the vomer has no contact with the nasal crest of the secondary palate. Figure $4(\mathrm{a})$ is available in color at wileyonlinelibrary.com/journal/oa. $200 \times 320 \mathrm{~mm}(300 \times 300 \mathrm{DPI})$ 

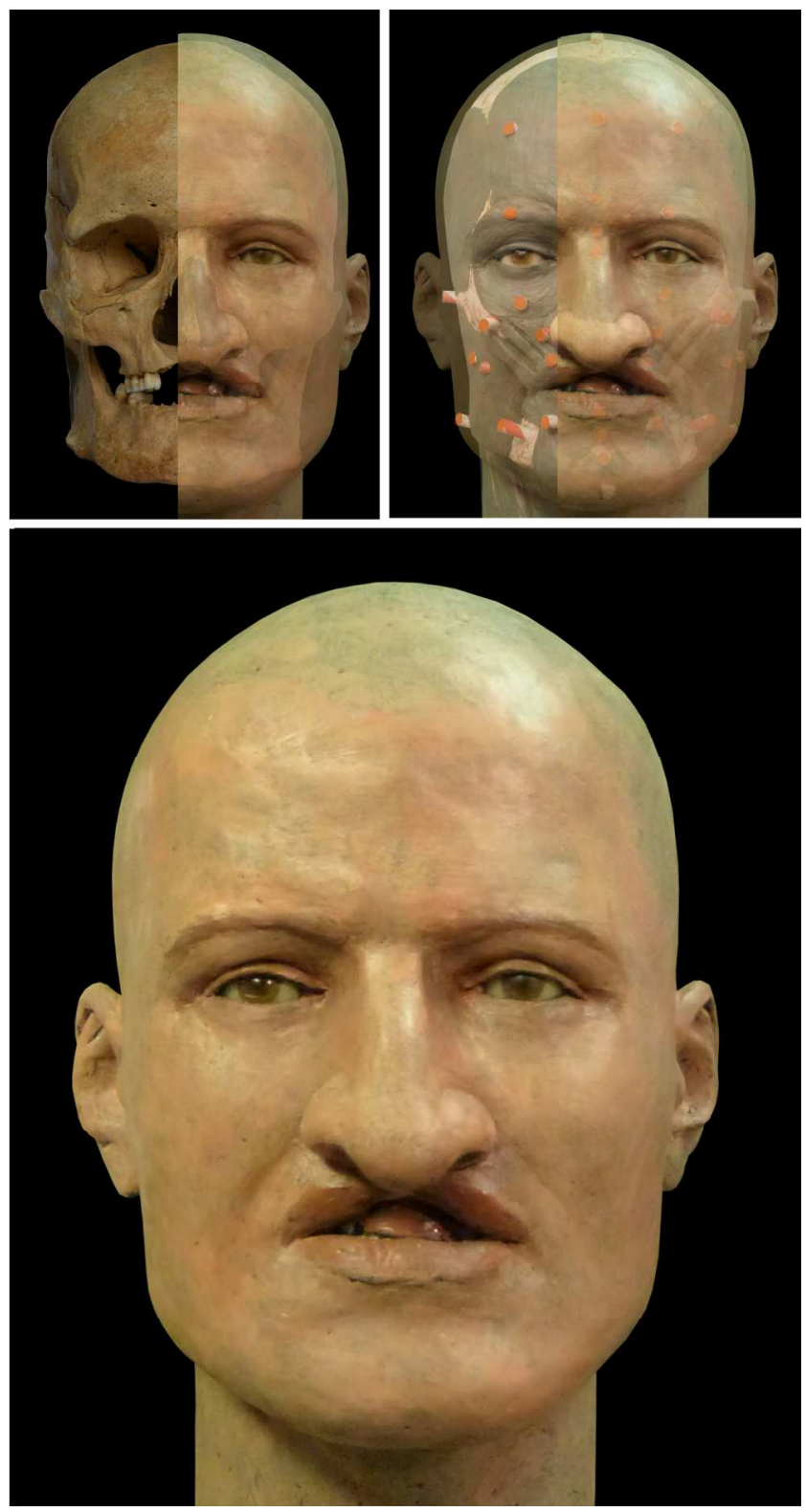

Figure 5. Sculpting facial reconstruction of the cleft man from the Middle Bronze Age cemetery of Firsovo 14. This figure is available in color at wileyonlinelibrary.com/journal/oa. $151 \times 285 \mathrm{~mm}(300 \times 300 \mathrm{DPI})$ 

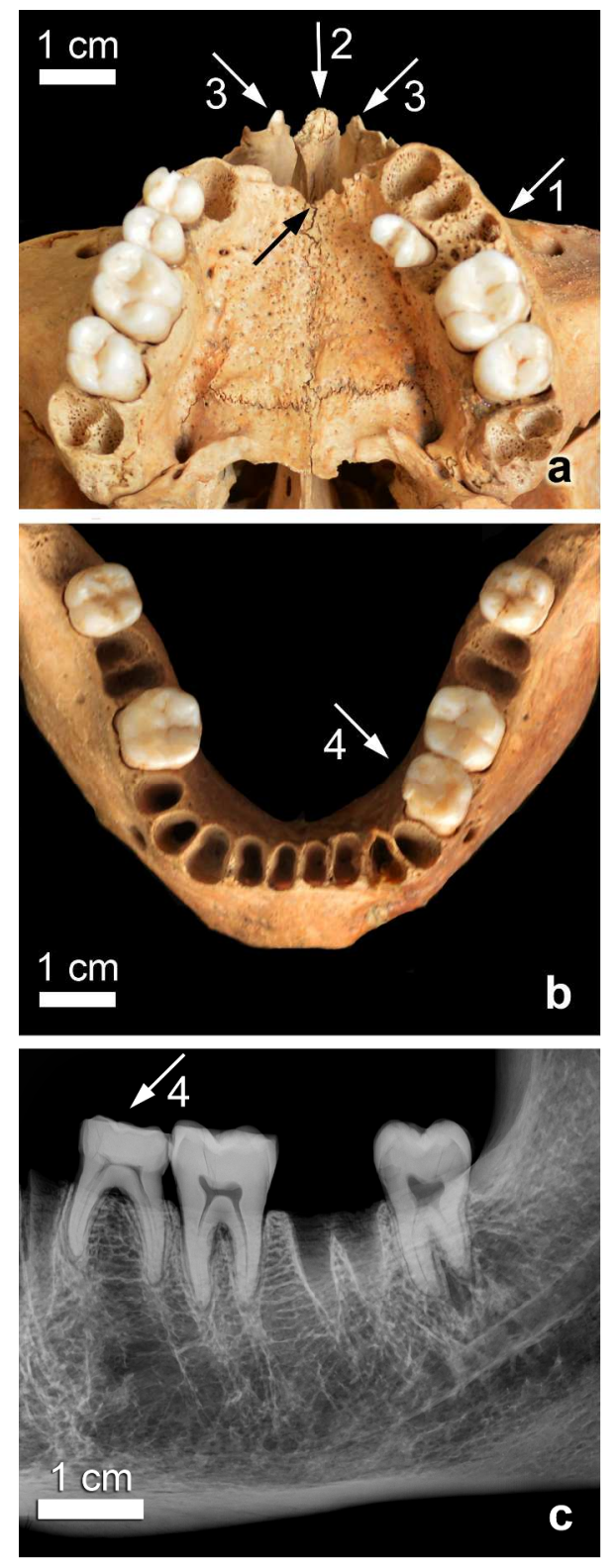

Figure 6. Photographs (a, b) and radiography image (c) of the dentitions of the cleft skull: (a) occlusal view of the maxilla showing the left second permanent premolar erupted palatally and socket of the retained but lost post mortem primary second molar (arrow 1); indicated premaxilla (arrow 2), nasal bones (arrows 3 ) and place of the incisive foramen (black arrow); (b) occlusal view of the mandible showing the retained left primary second molar (arrow 4); (c) the left side of the mandible with the primary second molar (arrow 4) retained due to hypodontia of the second permanent premolar; the third molar completely formed, with root apices closed. Figure 6(a)-(b) are available in color at wileyonlinelibrary.com/journal/oa. $115 \times 307 \mathrm{~mm}(300 \times 300$ DPI) 
Figure 7. Results of stable $\delta^{13} \mathrm{C}$ and ${ }^{15} \mathrm{~N}$ isotope analysis of the cleft individual and two Andronovo groups from the cemeteries of Rublevo and Chekanovskiy Log, plotted together with associated herbivores. $111 \times 84 \mathrm{~mm}(96 \times 96 \mathrm{DPI})$ 
Table 1. Buccolingual crown diameters of the permanent teeth in the cleft individual compared to those of the control group

\begin{tabular}{llll}
\hline Tooth $^{\mathrm{a}}$ & $\begin{array}{r}\text { Cleft } \\
\text { skull }\end{array}$ & \multicolumn{2}{c}{ Control group } \\
\cline { 3 - 4 } & \multicolumn{1}{c}{ Mean $(\mathrm{n})^{\mathrm{c}}$} & $\mathrm{SD}$ \\
\hline $\operatorname{Pr}^{1} \mathrm{R}$ & $7.75^{*}$ & $9.53(11)$ & 0.69 \\
$\operatorname{Pr}^{1} \mathrm{~L}$ & - & $9.59(13)$ & 0.67 \\
$\operatorname{Pr}^{2} \mathrm{R}$ & $7.49^{*}$ & $9.79(14)$ & 0.64 \\
$\mathrm{Pr}^{2} \mathrm{~L}$ & $7.33^{*}$ & $9.82(17)$ & 0.71 \\
$\mathrm{M}^{1} \mathrm{R}$ & 11.47 & $11.92(24)$ & 0.65 \\
$\mathrm{M}^{1} \mathrm{~L}$ & 11.38 & $11.97(22)$ & 0.59 \\
$\mathrm{M}_{1} \mathrm{R}$ & 10.88 & $11.14(20)$ & 0.64 \\
$\mathrm{M}_{1} \mathrm{~L}$ & 10.68 & $10.95(20)$ & 0.76 \\
\hline${ }^{\mathrm{a}} \mathrm{Pr}-$ premolar, $\mathrm{M}-$ molar (superscript: upper dentition; subscript: lower dentition); $\mathrm{R}-$ right, L \\
- left; \\
b values deviating by more than 2 SD from the control mean are marked as *; \\
${ }^{\mathrm{c}}$ nurber of observations.
\end{tabular}


Table 2. Measurements of the cleft skull compared to those of the control group

\begin{tabular}{|c|c|c|c|c|}
\hline \multirow[t]{2}{*}{ Abb. $^{a}$} & \multirow[t]{2}{*}{ Variables $^{\mathrm{b}}(\mathrm{mm})$} & \multirow{2}{*}{$\begin{array}{l}\text { Cleft } \\
\text { skull }^{\mathrm{c}}\end{array}$} & \multicolumn{2}{|c|}{ Control group } \\
\hline & & & Mean $(n)^{d}$ & $\mathrm{SD}$ \\
\hline Ml & Maximum cranial length ( $g-o p)$ & 189 & $189.8(26)$ & 7.48 \\
\hline M8 & Maximum cranial breadth (eu-eu) & 140 & $139.6(24)$ & 7.05 \\
\hline M17 & Cranial height $(b a-b)$ & 146 & $138.9(19)$ & 5.39 \\
\hline M5 & Cranial base length $(b a-n)$ & 108 & $107.2(17)$ & 3.05 \\
\hline \multirow[t]{2}{*}{ M9 } & Minimum frontal breadth $(f t-f t)$ & 99.1 & $95.8(23)$ & 4.26 \\
\hline & Facial base length (ba- incision) & $81.6^{*}$ & $89.9(16)$ & 2.60 \\
\hline M43 & Upper facial breadth (fmt-fmt) & 111.5 & $107.1(27)$ & 4.64 \\
\hline M45 & Bizygomatic breadth $(z y-z y)$ & 138.0 & $135.8(24)$ & 5.86 \\
\hline M47 & Total facial height $(n-g n)$ & 110.0 & $116.0(20)$ & 6.26 \\
\hline \multirow[t]{4}{*}{ M61 } & Maxillo-alveolar breadth (ecm-ecm) & 62.15 & $63.0(21)$ & 3.41 \\
\hline & Maxillo-alveolar length (incision-alv) & $37.9^{*}$ & $43.48(23)$ & 2.67 \\
\hline & Palatal length (incision-sta) & $33.4^{*}$ & 39.9 (19) & 2.69 \\
\hline & Palatal breadth between the canines & $18.3 *$ & $25.10(25)$ & 2.01 \\
\hline M63 & Palatal breadth between the second molars (enm & 38.67 & $40.16(18)$ & 3.31 \\
\hline $\mathrm{SC}$ & Minimum nasal bones breadth - simotic chord & $13.0^{*}$ & $9.17(29)$ & 1.78 \\
\hline $\mathrm{DC}$ & Interorbital breadth - dacrial chord $(d-d)$ & $28.3^{*}$ & $22.76(24)$ & 2.61 \\
\hline $\mathrm{DC} / 5$ & Interorbital breadth relative to cranial base lenght & $26.2 *$ & $20.75(16)$ & 2.17 \\
\hline $\mathrm{DC} / 45$ & Interorbital breadth relative to bizygomatic breadth & $19.9 *$ & $16.26(19)$ & 1.57 \\
\hline M50 & Maxillofrontale breadth $(m f-m f)$ & $26.8^{*}$ & $19.97(29)$ & 1.88 \\
\hline M51a & Orbital breadth (ect-d) & 42.0 & $40.96(21)$ & 2.26 \\
\hline M52 & Orbital height Bicondylar width & 30.45 & $31.52(24)$ & 2.42 \\
\hline \multirow[t]{2}{*}{ M54 } & Maximum nasal breadth (al-a/) & $33.6 * *$ & $24.36(30)$ & 2.04 \\
\hline & Nasal bones lenght (n-rhi) & 17.2 & $21.6(22)$ & 4.19 \\
\hline M68(1) & Maximum mandibular length & $98.0^{*}$ & $110.5(16)$ & 4.30 \\
\hline M70 & Height of mandibular ramus & 70.0 & $64.6(23)$ & 4.19 \\
\hline M65 & Bicondylar breadth & 128.0 & $120.4(15)$ & 6.12 \\
\hline M69 & Symphyseal height & 35.8 & $34.5(23)$ & 2.42 \\
\hline M70/47 & Height of mand. ramus relatively to total facial height & $63.6^{*}$ & $55.1(17)$ & 3.98 \\
\hline M69/47 & Symphyseal height relatively to total facial height & 32.6 & $29.9(20)$ & 1.53 \\
\hline \multicolumn{5}{|c|}{${ }^{\mathrm{a}} \mathrm{M}$ numbers - abbreviated measurements according to Martin (Martin and Saler, 1957). } \\
\hline \multicolumn{5}{|c|}{$\begin{array}{l}{ }^{\mathrm{b}} \text { Craniometric landmarks (Martin and Saler, 1957): alv - alveolon, ba - basion, } \\
\text { ectomolare, enm - endomolare, ect - ectoconchion, eu - euryon, } \mathrm{g} \text { - glabella, gn - } \\
\text { fronto-malare-orbitale, fmt - fronto-malare-temporale, ft - frontotemporale, ecm - } \\
\text { maxillofrontale, } \mathrm{n} \text { - nasion, op - opisthocranion, pr - prosthion, sta - staphylion, z } \\
\text { zygomaxillare } \\
\mathrm{c} \text { values deviating by more than } 2 \mathrm{SD}\left({ }^{*}\right) \text { and } 4 \mathrm{SD}\left({ }^{* *}\right) \text { from the control mean }\end{array}$} \\
\hline
\end{tabular}

